\title{
Healing Through Music and Dance in the Bible: Its Scope, Competence and Implications for the Nigerian Music Healers
}

\author{
C. O.Aluede* and D. B. Ekewenu** \\ *Theatre and Media Arts Department, Faculty of Arts, Ambrose Alli University, \\ Ekpoma, Edo State, Nigeria \\ **Department of Music, Delta State University, Abraka, Nigeria
}

KEYWORDS Healing. Illness. Music. Therapy

\begin{abstract}
This paper examines the use of music in healing as recorded in the Bible. The researcher gives a critical assessment of the healing exercises and classifies the kind of healing so achieved. This researcher concludes that music healing is real and far beyond speculation. Relying on biblical foundation of music healing, the researcher reveals that, the kind of music, the choice of instrument, the duration of performance, the intensity of the music, the setting of the healing exercise are significant contributions to the overall therapeutic potency of music, hence, Nigerian music healers are encouraged to learn from the Bible in evolving music healing techniques.
\end{abstract}

\section{INTRODUCTION}

The use of music/musical sounds in healing rites is receiving a serious attention as never before in the last two decades. The holy Bible provides instances of how music was used in the ancient times for healing purposes. Beyond healing, the Bible also talks of a musical genre which was used to destroy the walls of Jericho. Within the purview of this paper, how music heals, the disorders music can order and the kinds of healings achieved will be discussed extensively using the Bible as a foundation.

Different kinds of healing have been talked of relying on the Bible. Adamo (2004) and Fatokun (2004) attested to the fact that God is primarily concerned with the wholeness of man, hence His inclusion of medical institutions in the framework of creation. This He displayed by making trees, herbs and crops. Hackett (1981), Adedeji (1998) and Faseun (2005) also talk of healing in the Bible which required musical intervention. Beyond the Bible, they drew instances from selected Nigerian churches where music is used as a vehicle for healing.

Can music and dance heal all manners of ailments? Can the healing setting be the same for all manners of ailments? Can the musical instruments used in the various healing be the same? And can the various ailments be alleviated using the same volume of music? Answers to these questions are relevant in that they will lay some theoretical foundations for Nigerian contemporary music healers.

\section{THE BIBLICAL USE OF MUSIC: AN OVERVIEW}

Christians and non-Christian truth seekers have near good idea of the use of music in the Bible or in contemporary Christian churches. However, it is considered worthwhile to further draw the attention of readers by using relevant examples to establish the functional use of music in the Bible. This exercise will enhance the discourses which will follow this work. A critical study of the Bible reveals that the use of music in it is of many functions and they are:

- For praise and worship of God

- For merry making

- For mocking (Job 30:9)

- For thanks-giving

- For surprising and terrorizing enemies (Judges 7:18-20)

- For warding offevils(Exodus 28:35; 1 Samuel 16:16)

- For coronation of Kings (1 Kings 1:34, 39; 2 Kings 9:31)

- For confession and admonition

- For suiting troubled mind (1 Samuel 16:23)

- For prayer and supplication to God

- For prophesying (1 Samuel 10:5-6; 1 Kings 3:15)

- As accompaniment to work (Numbers 21:17; Judges 9:27 and Jeremiah 31:4-5).

- For healing his people. 
Citing the writings of Johannes Tinctoris (1435 -1511), Cole (1998: 83) remarked that music in the Bible played very many functions and in worship in our contemporary societies. To delight in God, to embellish God's praises, to increase the joy of the blessed, to make the militant church similar to church triumphant, to prepare for the accepted of divine benediction.

\section{THE CONCEPT OF ILLNESS AND ITS CAUSES IN THE BIBLE}

This segment attempts from historical viewpoint to examine illness and how it is viewed within the purview of the Bible and Bible history. Fatokun (2004) maintains that:

Suffering - pains and diseases as physical ills affecting the well-being of man are generally in the notion of the Jews punitive measures from God to man for his short comings or violation of divine rules, and are thus considered as moral evils. However, it is interesting to note that in spite of this view, God is still considered by the Jews as the "Great Medicine-Man" the Jehovah Rapha, the Healer of His people (see Exodus 15:26) and as such the afflicted basically look up to Him for help (Fatokun 2004:42)

Fatokun is not alone in this opinion. Aluede (2005:99) is of the view that disease is generally accepted to be caused by God, hence, relying on the Bible, he says "In Isaiah 19:22, Deutronomy 32:39 and Acts of the Apostles 9:8, 17 and 18, evidences abound that God smites and heals. God makes alive, wounds and heals, made Paul blind and consequently healed him". From the observations of the scholars above, it is without doubt very clear that God can and so causes illness to man perhaps for divine reasons.

What then is the Biblical concept of illness? Talking about the ancient Hebrew culture, Rathus (2000:12) opines that "childlessness and the development of repulsive abnormality, such as a boil, were grounds for divorce. After all, repulsiveness would dampen the mate's enthusiasm for reproducing". Therefore, barrenness was a form of illness (see Genesis 11:30, Gen. 29:31, and Gen. 25:21), physical sickness and plagues (See Deutronomy 28:59, 29:22, Job 1), Mental sickness (see 1 Samuel 16: 14:23) and poverty (see Haggai 1:5 \& 6).

\section{MUSIC HEALING IN THE BIBLE AND ITS KINDS}

Relying on Mereni’s (1997) model, music healing is of five kinds and they are:

a. Anxiolytic music therapy: Music meant to free one from fear, fright or anxiety.

b. Tensiolytic music therapy: Music meant to relieve one from physical or mental pain as a result of labour.

c. Algolytic music therapy: Music meant to relieve physical pain.

d. Psycholytic music therapy: Music meant to loosen a person from the grip of evil forces.

e. Patholytic music therapy: Music meant to relieve grief of bereavement, heavy loss or heavy burden borne on one's mind.

Having identified these five shades of musical intervention in the well-being of man, we will be examining the therapeutic applications of music in the Bible and the ailments which informed the objectives of the forms of musical types and intervention so applied. Although the Bible is ornamented with a lot of ailments where music was used to bring about well-being, for the purpose of this research, we shall limit our discussions to four and they are:

1. The invasion of Saul by evil spirits

2. David and the Ark of God

3. Jephtah's daughter's two months retreat

4. Paul and Silas in Prison.

\section{The Invasion of Saul by Evil Spirits}

Saul was sick and through investigation and diagnosis, it was discovered that the spirit of God had departed from him and was invaded by evil spirits (1 Samuel 16:14 - 23). The method of treatment was that David played harp for him to release Saul from the firm grip of evil spirits. The setting where this healing exercise was conducted was Saul's bedroom. The harp is an instrument known to have the power of playing melodies as well as harmonies. From the provisions in the Bible, the music was not danced to but performed solely to sedate Saul. David alone was recorded to be a known person who could play the music. This discovery therefore means it was not ensemble performance but directed for the aesthetic and therapeutic enjoyment of Saul. It may not be wrong to suggest that the music was soft and the results and follow-up of this healing is found in 1 Samuel $14: 23$ when it is thus recorded that

Whenever the spirit from God came upon Saul, David would take his harp and play. Then, relief would come to Saul; he would feel better and evil spirit would leave him.

The kind of music therapy applied in the 
above sense is the psycholytic music therapy and the sole aim was just to free the patient (Saul) from the grip of evil spirits.

\section{David and the Ark of God}

The antecedents associated with the Ark of God, that is how a person who wanted to save it from falling was struck dead and his unworthiness to house the ark were some of the major reasons for David's fear and hesitation in bringing the ark to his home. In the house of Obed, where the ark was, God blessed his household and everything he has (1 Samuel 6:12).

$A b$ initio, King David was under the serious threat of fear and so did not want the ark. Having made up his mind to bring the ark home, a collective musical intervention was sought. The Bible said: "David, wearing a linen ephod, danced before the Lord with all his might, while he and the entire house of Israel brought up the ark of the Lord with shouts and the sounds of trumpet" (1 Samuel 6:14-5). The biblical excerpt above talks of David dancing with his might, the kind of music was associated with shouting and the trumpets were also employed. Trumpets are known for vulgarity and brilliance. The setting for the musical performance happened to be the street side with the whole lot of Israelites in attendance.

Hearing very brilliant music with high pitches attenuates fright, anxiety or fear. Invariably, David was subjected to anxiolytic music therapy. There and then, his mind rose above fear and he danced very vigorously, came to the once dreaded ark, made sacrifice and blessed the land of Israel and his household.

\section{Jephtah's Daughter's Two Months Retreat}

The Bible gives a very clear remark on the vow of Jephtah and his only daughter who then became the object of sacrifice. To be prepared for the intended sacrifice, his daughter then requested for two months to mean herself.

The Bible is ornamented with the concept of weeping, wailing and great lamentation. Of these terms italicized above, one may not be wrong to say that they also had strong relationship with singing. In our present day societies, women are apt to crying more easily than the men, and when they cry, they hum or sing accordingly. Relying on the Bible, Cole (1998:17) opined that
Women often seem to be music makers: see the stories of Miriam (Ex. 15:20), Deborah (Judges 5), Jephtah's daughter (Judges 11:34) and the women meeting David after he had slain the Philistine (1 Samuel 18:6-7). They were the ones who sang the dirges in times of lamentation (2 Samuel 1:12-18; 2 Chronicles 35:25).

From the Biblical account, the event that will culminate to Jephtah's daughter being sacrificed was grief filled hence she asked for some time to go into the wilderness to bewail and bemoan her incipient death. That she choose the wilderness as the place to stay for sometime means she opted for a calm and serene environment. This setting is significant because every Bible student may be touched with the similarities with John's mission in the wilderness, Jesus' mission in the garden of Gethsemane. These factors informed the researcher when he used the term, the two months' retreat.

Put simply, she went to the wilderness to be free from worldly cares and to combat great grief, pain and tension associated with her being sacrificed shortly. The kind of musical intervention which she got from this retreat is both tensiolytic and patholytic music therapy.

\section{Paul and Silas in Prison}

"And at midnight, Paul and Silas prayed, and sang praises unto God: And the prisoners heard them" (Acts 16;25).

Middle Eastern prisons were never known as places of comfort, but were frequently nothing more than dreary dungeons. There were no toilet facilities and prisoners lay with their feet fastened in wooden stocks on the bare ground. Under such circumstances, it must have seem highly unusual to hear two people singing praises to God (special insert to the Herald of Christ Kingdom January/February, 2006).

From the quotation above, it is obviously clear that the prison where Paul and Silas were kept was not good for human habitation. It was a place of tension, mental and physical pains. In that deplorable condition they sang, the objective of the singing was to attenuate the tension, mental and physical pains associated with their imprisonment. Therefore, the kind of music therapy which they sought in songs was a combination of Tensiolytic and Algolytic music therapy. 


\section{HOW MUSIC AFFECTS US}

Singing regulates, sustains and deepens the breath, increases the sensitivity of auditory system and refines the internal sensing process. Singing can resonate the entire physical body and the electro-magnetic field, fully engage the mind, and give the emotions a vehicle for expression and produce an overall sense of wellbeing. When we combine the singing of sustained pitches with specific vowels and directed system and calm our nervous system. In short, the quality of our voice can be a reflection of our emotional, physical and spiritual condition - our healthfulness (McClellan 1988: 72).

Concentrating we can, in addition, revitalize our internal organs, tone our endocrine glands. Sharing a similar view, Staricoff (2003) in her research in a hospital in United Kingdom remarked that beyond ancient speculations, she observed that while performing line music for patients awaiting surgery, their anxiety and their high blood pressure were corrected.

Ever since the creation of the universe, music has had a tremendous effect on mortals. This accounts for the reason why music has been accepted in healing singularly or incorporated in healing rituals in most communities of the world. Music affects man in numerous ways: apart from being an entertainment tool, music is used as audio-analgesis to alleviate or lessen pain, hence, the term: music as medicine, music is used vibrational therapy sessions to affect physiological changes such as lowering blood pressure, heart rate and muscle tension. Another benefit of music in healing is to stir our emotions and feelings to help us deal with grief, sadness and anger (Cottrell 2000).

\section{BIBLICAL HEALING THROUGH MUSIC AND THE IMPLICATIONS FOR THE NIGERIAN MUSIC HEALERS}

Else where in this study, it was mentioned that music if performed live to patients awaiting surgery could calm both high blood pressure and anxiety. The same is also applicable to pregnant women in labour. Today, music therapists function in clinics and hospitals as well as schools. However, little is yet known of it in Nigeria. Although there are music healing traditions all over Nigerian ethnic groups, there is a lacunae on the theories that facilitate music healing among Nigerian peoples, the kinds of songs, musical instruments, the duration of musical intervention, the kind of setting to mention just a few.

From the four biblical examples of musical intervention highlighted in this work, inferences will be drawn in this segment on contemporary use of music in healing. These will be discussed under (1) Healing setting (b) Choice of Music (c) Choice of Instruments (4) volume of music (5) General attributes of music.

\section{Healing Setting}

Just as it is in modern schools where music rooms are different from the ordinary classrooms, the venue for healing should be a calm place devoid of ambient sounds but those intended for the listening pleasure of the patient. The setting needs be neat and ornamented with beautiful flowers in natural state or good painting. These attributes help in building the confidence of the patient thus a good rapport is facilitated between the therapist and his client

\section{Choice of Music}

Music which is known to the client is better used. Studies have revealed that patients respond more to genres from their musical culture than any other hence the stress on pan-cultural music for healing.

\section{Choice of Musical Instruments}

From the accounts in the Bible, certain facts emerge. And they are:

i. Melodic/harmonic instruments were used in the treatment of psychosomatic cases. The major instrument mentioned is the Harp (lyre).

ii. Trumpets/percussion instruments were used to fight cases bordering on fears and anxiety. Trumpets are usually low, the same could also be said of the percussion instruments.

iii. Vocal music was used whether melodically or in harmony to ease tension, emotional pains or physical pain.

Just as it is believed that the fruits in a season heal the ailments of the season, music therapists should diagnose ailments and also try make accurate suggestion of the instruments which will best yield fruitful results in healing. 


\section{Volume of Music}

Loud music creates tension, increases perspiration rate and decreases sense of concentration. However, if it is moderately loud, it wards off fear.

Soft music cools the mind, relaxes the nerves of the listener and it also serves as a soporific. Drifting into sleep commonly occurs when music is soft and the listener struggles to hear it.

\section{CONCLUDING REMARKS ON HEALING ATTRIBUTES OF MUSIC}

Beyond mere speculation, music is beginning to be known to have healing functions. These healing functions should not be seen in the vein of wound healing. Music aids movements, corrects speech disorder, enhances good character formation, enhances team work, and through songs the ills and vices in the society are unveiled. This in turn serves as deterrents to others.

From this paper, it has been specifically observed that music attenuates tension, anxiety, emotional depression, and redirects individuals by strengthening them. Music also helps in geriatric cases. If music has such a very wide latitude of benefit to mankind outside entertainment, it is therefore suggested that Nigerian music healers should encourage a multidisciplinary approach to music as therapy where medical doctors, ethnomedical practitioners, psychologists to mention but a few will be involved so that healing will be more meaningful and wholistic.

\section{REFERENCES}

Adamo DT 2004. Healing in the Old Testament Context. In: SO Abogunrin et al (Eds.): Biblical Healing in African Context 3 NABIS.
Adedeji FA 1998. The theology and practice of music therapy among Nigerian indigenous churches: Christ Apostolic Church as a Case Study, Journal of Arts and Ideas, 1(2): 34-35.

Aluede CO 2005. An Appraisal of Healing in African Belief and Modern Day Pentecostal Churches. Nigerian Journal of Christian Studies, 1: 93 -106

Cole B 1998. Music \& Morals. New York: Alba House.

Cottrell A 2000. What is Healing Music? www.healing music.org. Retrieved 23/2/2005.

Faseun F 2005. Music as an Enhancer of Spiritual growth and commitment: A Study of the practices in selected Aladura churches in Nigeria. Conference Paper at the $6^{\text {th }}$ Annual Musicology Society of Nigeria Conference held in Nnamdi Azikiwe University, Awka, between $9^{\text {th }}-13^{\text {th }}$ May.

Fatokun SA 2004. GOD, A Medicine Man: A Historical Appraisal of Christianity and Medicine from the Ancient times to Date. In: Egbe Ifie (Ed.): Lambart Eradiri: The Legend in the Oasis of the Niger. Ibadan: Opotoru Books.

Gaston ET 1968. Music in Therapy. New York: The Macmillan Company.

Hacket R 1981. Recent Developments in the Healing Concepts and Activities of the Aladura Churches. African Notes, 8(2): 55 - 58.

Kohlenberger III JR 1979. The NIV Inter-Linear HebrewEnglish Old Testament. Michigan: Zondervan Publishing House.

Lee Mee K 1994. Chant: The Origins, Form, Practice and Healing Power of Gregorian. New York: Bell Tower.

McClellen R 1988. The Healing forces of Music. New York: Amity House.

Meremi AE 1997. Traditional African Concept of Sound/ Motion: Its Implication for and application in Music therapy British Journal of Music Therapy, 11(1\&2): Vol. X/162: 66-72.

Meremi AE 2004. Music Therapy in Medical History. Lagos: Apex Books Limited.

Meremi AE 2004. Music Therapy: Concept, Scope and Competence. Lagos: Apex Books Limited.

Rathus SA 2000. Human Sexuality. London: Allyn and Bacon.

The Herald of Christ's Coming 2006. Rejoicing in Tribulation. Special Insert to the Herald, January/ February (2006). 